\title{
Perioperative challenges in patients with giant occipital encephalocele with microcephaly and micrognathia
}

\author{
Hukum Singh, Daljit Singh, DP Sharma, Monica S Tandon ${ }^{1}$, Pragati Ganjoo ${ }^{1}$ \\ Departments of Neurosurgery and ${ }^{1}$ Anaesthesia, G. B. Pant Hospital, New Delhi, India
}

\section{ABSTRACT}

Meninigo-encepahlocoele (MEC) is a common neurosurgical operation. The size of MEC may vary which has bearing with its management. The association of MEC with micrognathia and microcephaly is rarely reported. The association poses special problem for intubation and maintenance of anaesthesia. Giant MEC may lead to significant CSF loss resulting in hemodynamic alteration. The prior knowledge and care in handling the patient can avoid minor as well as major complications.

Key words: Giant meningoencephalocoel, micrognathia, microcephaly

\section{Introduction}

Occipital encephalocele are described as giant when they are larger than the head from which they arise. ${ }^{[1]}$ The incidence of encephalocele is 1 per 5000 live birth. ${ }^{[2]}$ The association of microcephaly and micrognathia is extremely rare and has been attributed to partial deletion of chromosome 13q. ${ }^{[3]}$ We present a case of giant occipital encephalocele associated with microcephaly and micrognathia, a rare entity and in particular the associated problems during anesthesia and surgical intervention.

\section{Case Report}

A 5-month-old male second child, from a nonconsanguineous marriage presented with a progressively increasing swelling at the back of head, since birth. He was delivered by caesarean section. Antenatal ultrasound picked a swelling at back of neck with no other abnormality. The child was taking feeds

\begin{tabular}{|l|l|}
\hline \multicolumn{2}{|c|}{ Access this article online } \\
\hline Quick Response Code: & Website: \\
\hline & www.ruralneuropractice.com \\
\cline { 2 - 3 } & \\
\hline
\end{tabular}

normally and moving all four limbs equally. Child had small jaw, receding chin with no breathing problem. Tongue was normal. His weight was $6 \mathrm{~kg}$, and the head circumference was $30 \mathrm{~cm}$ with a bulging anterior fontanelle. There was a large occipital swelling which was tense, cystic measuring $22^{\prime} 13 \mathrm{~cm}$ arising from posterior part of head. Lower part of swelling was extended up to mid-dorsal region [Figure 1].

Trans illumination test of the swelling was positive: Magnetic resonance imaging (MRI) revealed the cystic nature of the giant occipital encephalocele with a very small amount of brain tissue [Figure 2] There was a defect of 32' $30 \mathrm{~mm}$ in occipital bone. MR venography revealed no venous system involvement [Figure 3].

The child was taken up for surgery after obtaining informed consent. Before intubation, the encephalocele was aspirated slowly and about $150 \mathrm{ml}$ of fluid was aspirated. The child was intubated in supine position with head supported from below by two people, over the edge of OT table [Figure 4].

After intubation, the child was placed in prone position for surgery. To facilitate painting and draping, encephalocele was pulled with thick thread toward the roof.

Excision of the encephalocele sac was done with the herniated glial tissue [Figure 5]. Primary water tight closure of dura was done. The cranial defect

Address for correspondence:

Dr. Hukum Singh, Department of Neurosurgery, Flat No 107, Block 2, Multi Storey Flats, Motia Khan, Pahar Ganj, New Delhi 110 055, India. E-mail: drhsingh2008@hotmail.com 


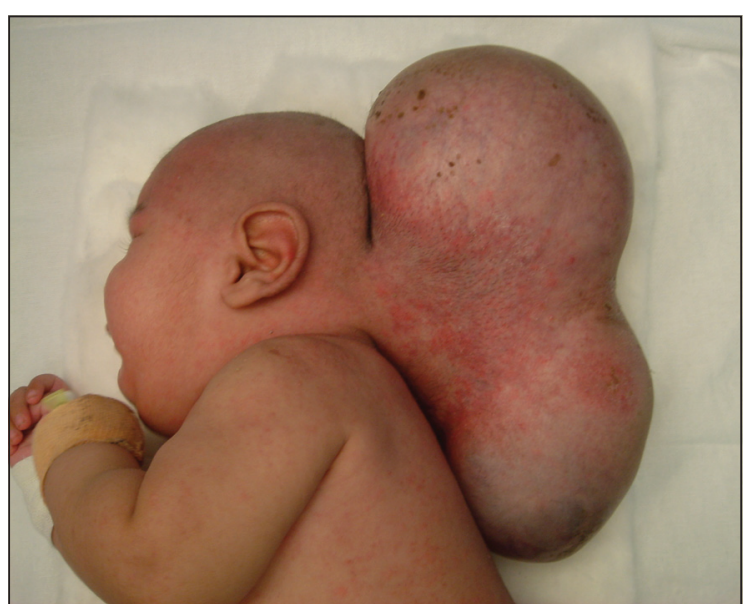

Figure 1: Clinical photograph showing the giant occipital encephalocele associated with microcephaly and micrognathia

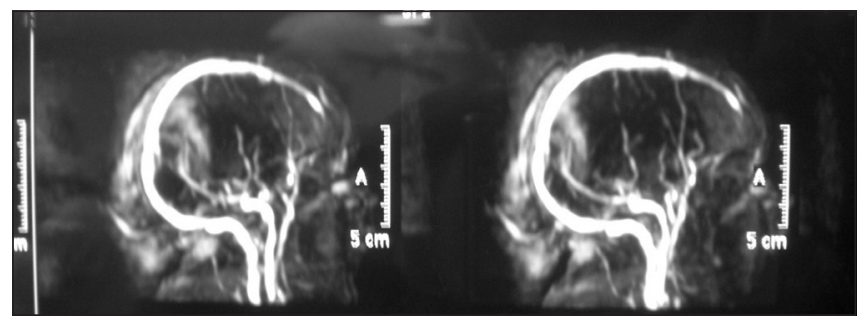

Figure 3: MR venography showing there is no venous system involvement

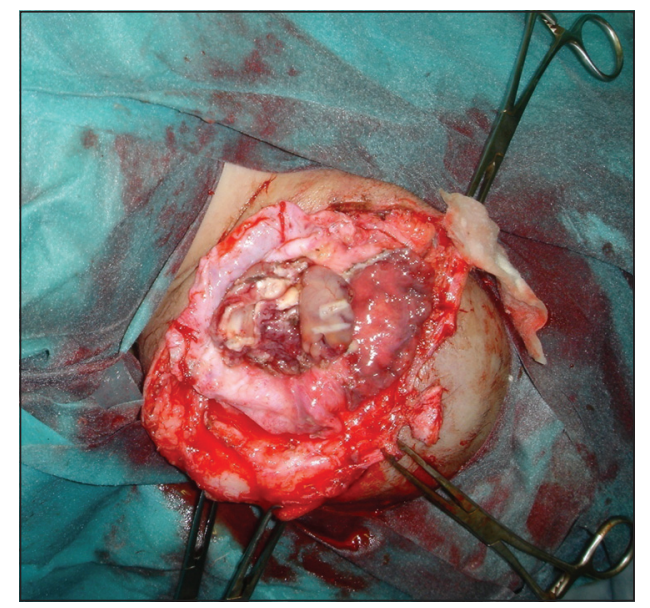

Figure 5: Intraoperative photograph showing the excision of sac

was covered with spongistone $\left(\right.$ Gelfoam $\left.^{\circledR}\right)$ for later cranioplasty.

On third postoperative day, anterior fontanelle was tense. NCCT head revealed hydrocephalus, and a medium pressure ventriculo peritoneal shunt was done. Postoperative period was uneventful and the child was discharged on thirteen postoperative day. Cranioplasty for the bony defect was advised but parents refused due to personal reasons and took discharge for surgery at later date.

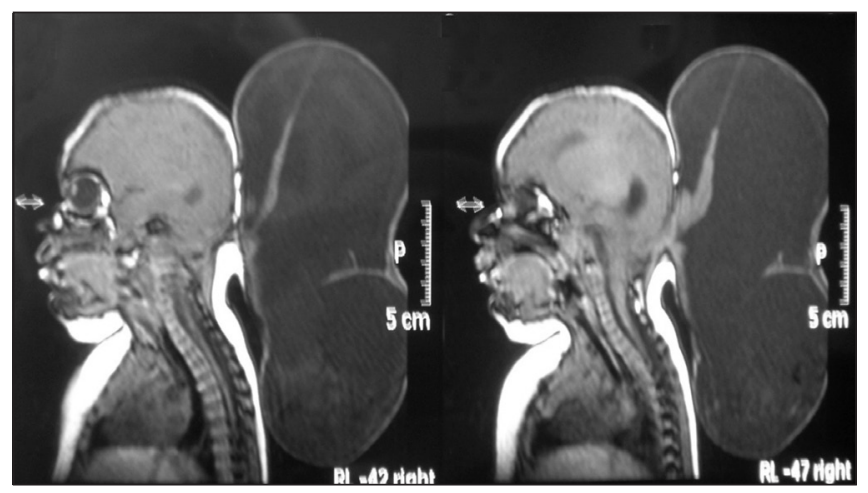

Figure 2: MRI brain showing the cystic nature of giant occipital encephalocele with small amount of brain tissue

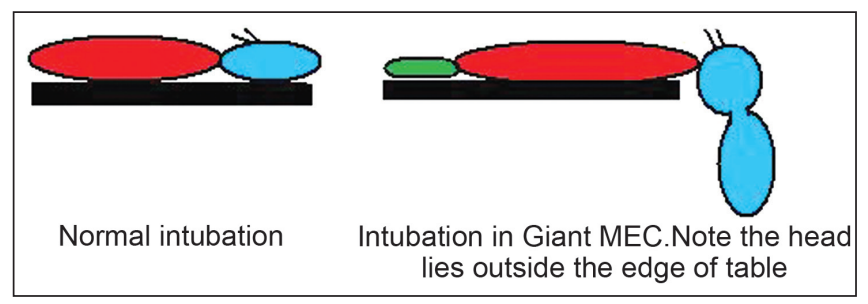

Figure 4: Schematic representation of position on OT table for intubation in normal and in patient with giant meningo encephalocele.

\section{Discussion}

Encephalocele is a congenital anomaly where herniation of the cranial contents occurs through a congenital defect in cranium. It account for $10-20 \%$ of all craniospinal dysraphisms. ${ }^{[4]}$ Occipital encephalocele generally occur through a bony defect in the occipital bone. It may extend into the foramen magnum and can involve the posterior arch of atlas. Occipital encephalocele represent approximately $85 \%$ of lesions seen in the western hemisphere. ${ }^{[5]}$ The underlying basis for the extrusion of brain tissue protruding from the meninges and CSF in encephalocele is a primary abnormal mesodermal defect. ${ }^{[6]}$ Giant occipital encephalocele associated with microcephaly and micrognathia is extremely rare. ${ }^{[1]}$ In these patients, there can be associated lesions including agenesis of corpus callosum, hypoplasia of cerebellum, meningocele, and hydrocephalus. Coexistent hydrocephalus may occur due to torsion of the aqueduct or aqueductal stenosis. Hydrocephalus may also set in after excision of the encephalocele due to changes in the CSF dynamics. In our case, hydrocephalus developed on third postoperative day for which we had put a ventriculo peritoneal shunt.

Magnetic resonance imaging (MRI) and magnetic resonance venography (MRV) is the optimal investigation to visualize the contents of the sac and its relationship to venous sinuses. ${ }^{[7,8]}$ Visual evoked response (VER) is of use in giant occipital 
encephalocele to find out whether the sac contains functional tissue from visual cortex. ${ }^{[9]}$

Strategy regarding surgical intervention depends upon the amount of neural tissue in the sac, state of CSF pathway, neurological status of the patient and presence or absence of associated congenital anomalies elsewhere in body ${ }^{[10]}$ It is technically difficult to intubate such patients as well as cleaning and draping of surgical site. Intubation can be facilitated by draining the CSF prior to induction or by bringing the child to the edge of the table so that the entire giant encephalocele lies below the table top. However, it warrants holding the child carefully. Cleaning and draping is facilitated by holding the swelling with suture or Allis forceps which allow visualization of the swelling with skull junction for proper cleaning.

When giant encephalocele are associated with microcephaly and micrognathia, it is a predictor of poor outcome. ${ }^{[11]}$ Folic acid and iron supplementation during pregnancy can prevent this type of congenital anomalies. ${ }^{[11,12]}$ Prenatal diagnosis of encephalocele is possible through ultrasonography, maternal serum alfa feto protein (MSAFP) and amniocentesis. ${ }^{[13]}$ Endoscopic third ventriculostomy can be used to treat hydrocephalus when associated with occipital encephalocele with limited success. ${ }^{[14]}$

Neuroanesthetist should be attentive for difficult intubation and careful securing of endotracheal tube in prone position. Other perioperative problems are serum electrolyte imbalance which may occur during aspiration of CSF, hypothermia and blood loss. ${ }^{[15]}$ Sudden loss of CSF during opening of sac may trigger hemodynamic changes such as bradycardia and even cardiac arrest. Continuous arterial monitoring and slow controlled efflux of CSF is recommended.

Presence of large occipital sac poses difficulties in positioning for intubation. Further the fear of compression and rupturing the sac, child cannot be positioned supine. Moreover there is limited neck extension. Various options for intubation are: Intubation in lateral position, ${ }^{[16]}$ placing the child's head beyond the edge of the table with an assistant supporting it, ${ }^{[5]}$ lifting the baby off the table with the help of two assistants. ${ }^{[17]}$

The diagnosis of micrognathia in fetus can be successfully made with ultrasound using jaw index ${ }^{[18]}$ However, in neonate the receding jaw, small airways and difficulty in feeding can prompt for micrognathia. There are several syndrome associated with it like Pierre Robin syndrome, Seckel syndrome, and progeria. ${ }^{[19]}$ It can even be nonsyndromic as in our case.

The management of such cases involves careful selection and involvement by a team of doctor including anesthetist, pediatrician, neurosurgeon, and craniofacial surgeon.

\section{References}

1. Agrawal D, Mahapatra AK. Giant occipital encephalocele with microcephaly and micrognathia. Pediatr Neurosurg 2004;40:205-6.

2. Mealey J Jr, Dzenitis AJ, Hockey AA. The prognosis of encephaloceles. J Neurosurg 1970;32:209-18.

3. Chen CP, Liu FF, Jan SW, Wang KG, Lan CC. Prenatal diagnosis of partial monosomy $13 \mathrm{q}$ associated with occipital encephalocele in a foetus. Prenat Diagn 1996;16:664-6.

4. Andarabi Y, Nejat F, El-Khashab M. Progressive skin necrosis of a huge occipital encephalocele. Indian J Plast Surg 2008;41:82-4.

5. Walia B, Bhargava P, Shandu K. Giant occipital encephalocele. MJAFI 2005;61:293-,4.

6. Raja RA, Qureshi AA, Memon AR, Ali H, Dev V. Pattern of encephaloceles: A case series. J Ayub Med Coll Abbottabad 2008;20:125-8.

7. Chapman PH, Sweaningen B, Cavines VS. Subtorcular occipital encephalocele: Anatomic considerations relevant to operative management. J Neurosurg 1989;71:375-81.

8. Naidich TP, Altman NR, Braffman BH, McLone DG, Zimmerman RA. Cephalocele and related malformations. Am J Neuroradiol 1992;13: 655-90.

9. Engel R, Buchan GC. Occipital encephaloceles with or without visual evoked potentials. Arch Neurol 1974;30:314.

10. Nejmi K, Nebi Y, Ismail D, Siddik K. Prognostic factors in patients with occipital encephalocele. Pediatr Neurosurg 2010;46:6-11.

11. Agrawal A, Lakhkar BB, Lakhkar B, Grover A. Giant occipital encephalocele associated with microcephaly and micrognathia. Paediatr Neurosurg 2008;44:515-6.

12. Lorber J, Schofield JK. The prognosis of occipital encephalocele. Z Kinderchir Grenzgeb 1979;28:347-51.

13. Chatterjee MS, Bondoc B, Adhate A. Prenatal diagnosis of occipital encephalocele. Am J Obstet Gynecol 1985;153;645-7.

14. Mcorthy RK, Rajshekhar V. Management of hydrocephalus associated with occipital encephalocele using endoscopic third ventriculostomy -report of two cases. Surg Neurol 2002;57;351-5.

15. Creighton RE, Rolton JE, Meridy HW. Anaesthesia for occipital encephalocele. Can Anaesth Soc J 1974;21:403-6.

16. Bissonnette B. Pediatric neuroanaesthesia: Beyond the theory. In: Badgewell IM, editor. Clinical Pediatric Anaesthesia. 1st ed. Philadelphia: Lipincott Raven 1997; p 339-45.

17. Manhas Y, Chinnan NK, Singh AK. Neonatal airway management in occipital encephalocele. Anesth Analg 2006;103:1632.

18. Paladini D, Morra T, Teodoro A, Lamberti A, Tremolaterra F, Martinelli P. Objective diagnosis of micrognathia in the fetus: The jaw index. Obstet Gynecol 1999;93:382-6.

19. Gunn TR, Tonkin SL, Hadden W, Davis SL, Gunn AJ. Neonatal micrognathia is associated with small upper airways on radiographic measurement. Acta Paediatr 2000;89:82-7.

How to cite this article: Singh $\mathrm{H}$, Singh D, Sharma DP, Tandon MS, Ganjoo P. Perioperative challenges in patients with giant occipital encephalocele with microcephaly and micrognathia. J Neurosci Rural Pract 2012;3:68-70.

Source of Support: Nil. Conflict of Interest: None declared. 